\title{
Amino Acid Derivative
}

National Cancer Institute

\section{Source}

National Cancer Institute. Amino Acid Derivative. NCI Thesaurus. Code C73539.

Any derivatives of amino acids that containing amino $(-\mathrm{NH} 2)$ and carboxyl $(-\mathrm{COOH})$ groups. 